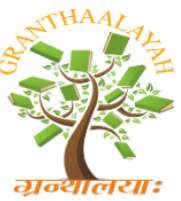

$$
\begin{aligned}
& \text { INTERNATIONAL JOURNAL OF RESEARCH - } \\
& \text { GRANTHAALAYAH } \\
& \text { A knowledge Repository }
\end{aligned}
$$

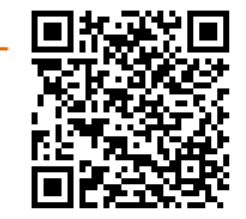

Science

\title{
EFFECT OF SOWING DATES ON THE TOBACCO CATERPILLAR [Spodoptera litura (FABRICIUS)], POPULATION, LEAF DAMAGE AND YIELD OF GROUNDNUT
}

\author{
Paras Nath ${ }^{1}$, S. N. Rai ${ }^{* 1}$, Ram Keval ${ }^{2}$ \\ ${ }^{1}$ Department of Entomology \& Plant Pathology, College of Agriculture, Fisheries and Forestry, \\ Fiji National University, P.O. Box 1544, Nausori, Fiji Islands \\ ${ }^{2}$ Department of Entomology \& Agricultural Zoology, Institute of Agricultural Sciences, \\ Banaras Hindu University, Varanasi, Uttar Pradesh, India
}

\begin{abstract}
The effect of sowing date of groundnut on the population buildup of tobacco caterpillar, Spodoptera litura (Fab.) and its effect on leaf damage (\%) and yield was studied at the Agricultural Research Farm of the Banaras Hindu University, Varanasi, Uttar Pradesh, India during rainy season consecutively for three cropping years. The tobacco caterpillar average population and groundnut leaf damage $(\%)$ was found maximum in the groundnut crop sown on 20th July followed by 5th July and 20th June during all the three years of study. The first infestation of tobacco caterpillar was observed at 45 days after sowing which disappeared 135 days after sowing. The interaction effect of sowing dates and the periods of observation on the leaf damage was found significant. The yield recorded from groundnut crop sown on 20th June was found maximum while the crop sown on 20th July recorded minimum yield.
\end{abstract}

Keywords: Groundnut; Leaf Damage; Population; Sowing Date; Tobacco Caterpillar; Yield.

Cite This Article: Paras Nath, S. N. Rai, and Ram Keval. (2017). "EFFECT OF SOWING DATES ON THE TOBACCO CATERPILLAR [Spodoptera litura (FABRICIUS)], POPULATION, LEAF DAMAGE AND YIELD OF GROUNDNUT." International Journal of Research - Granthaalayah, 5(8), 252-259. 10.29121/granthaalayah.v5.i8.2017.2220.

\section{Introduction}

Groundnut (Arachis hypogaea L.) is an important oilseed crop which occupies first place in India in respect of acreage and production. It is grown under wide range of soil and climatic conditions in different states of India. About 90 per cent of the groundnut is grown under rain fed condition (Reddy, 1988). The cultivation of improved varieties plays a pivotal role in increasing the production of crops but, at the same time, it also invites a wide spectrum of insect pests. About 100 species of insect pests are known to feed on groundnut and about a dozen are of economically important (Reddy, 1988). Nath and Singh (1998a) have listed 38 species of insect pests infesting groundnut crop at Varanasi. They have further reported that Insect pests causes 
severe damage to the crop and contributes significantly in minimizing the productivity of the crop. Most of the pesticides that are used in cotton, rice, pulses, oilseeds and vegetable crops had shown ill effects on human health and environment (Raghunathan, 1996). Different strategies have to be involved for keeping the pest in check and stabilizing the productivity of the cropping system. Date of sowing is one of the crop habitat diversifications that are to be looked into, to minimize the incidence of insect pests on groundnut crop so that its yield can be enhanced. The date of planting takes advantage of the absence of the pest or avoids susceptible stage of the crop. It prevents carryover of pests from early sown crop to late sown crop and prevents buildup of damaging populations (Singh, 1999). Kathryn et al, (2014) reported on the basis of their experiment that sowing dates can be used as a pest control measure against insect pests of chilli, it is concluded that early sowing (January 15th or January 30th) resulted in low incidence of aphids, thrips, jassids, whitefly and fruit borer except mites. Such low level of insect pest caused less crop injury which resulted in enhancing green pod yield of chilli. Keeping these facts in view, the effect of sowing dates of groundnut on the population of tobacco caterpillar, Spodoptera litura (Fab.), and its effect on leaf damage and yield of groundnut was studied.

\section{Materials and Methods}

Field experiment was conducted at the Agriculture Research Farm, Banaras Hindu University, Varanasi, Uttar Pradesh, India following Randomized Block Design with three sowing dates as treatments and six replications. The groundnut cultivar 'Chitra' was grown following recommended cultivation practices and sowing was done maintaining $20 \mathrm{~cm}$ x $40 \mathrm{~cm}$ plant to plant and row to row distance on $20^{\text {th }}$ June, $5^{\text {th }}$ July and $20^{\text {th }}$ July during rainy season consecutively for three years. The first hand hoeing and weeding was done three weeks after sowing and thereafter before commencement of flowering. No plant protection measures were exercised during the period of field experimentation.

The experimental crop was monitored on regular basis for incidence of insect pest and the observations were recorded by observing one-meter row length as soon as the infestation of tobacco caterpillar was noticed in the field and thereafter at fortnightly interval. The tobacco caterpillar population data were transformed as $\sqrt{x+0.5}$ while Arc sine transformation was followed in case of groundnut leaf damage (\%) data. The transformed data of tobacco caterpillar population and groundnut leaf damage and original yield data $(\mathrm{q} / \mathrm{ha})$ were analyzed for testing the significance of difference.

\section{Results and Discussion}

The population of tobacco caterpillar recorded in the groundnut crop sown on $20^{\text {th }}$ June, $5^{\text {th }}$ July and $20^{\text {th }}$ July during different years of study differed significantly. The population of tobacco caterpillar was maximum in the groundnut crop sown on $20^{\text {th }}$ July and minimum in the $20^{\text {th }}$ June sown crop. The groundnut crop sown on $5^{\text {th }}$ July exhibited medium range of pest population (Table 1). The interaction effect of sowing time and period of observation showed significant effect on the population of tobacco caterpillar during all three years of study. 
Table 1: Effect of date of sowing on the population of tobacco caterpillar [Spodoptera litura (Fab.)] (average of three years)

\begin{tabular}{|c|c|c|c|c|c|c|c|c|}
\hline \multirow{2}{*}{$\begin{array}{l}\text { Date of } \\
\text { Sowing }\end{array}$} & \multicolumn{8}{|c|}{ Population (per metre row length) DAS } \\
\hline & 45 & 60 & 75 & 90 & 105 & 120 & 135 & Average \\
\hline $20^{\text {th }}$ June & $2.7(1.7)$ & $3.8(2.0)$ & $4.9(2.3)$ & $4.7(2.2)$ & $4.1(2.1)$ & $3.1(1.8)$ & $1.6(1.4)$ & $3.5(1.9)$ \\
\hline $5^{\text {th }}$ July & $1.9(1.5)$ & $3.8(2.0)$ & $5.5(2.4)$ & $5.6(2.4)$ & $5.3(2.3)$ & $3.8(1.9)$ & $2.3(1.6)$ & $4.0(2.0)$ \\
\hline $20^{\text {th }}$ July & $1.5(1.3)$ & $3.9(2.0)$ & $6.8(2.6)$ & $7.5(2.8)$ & $6.7(2.6)$ & $4.9(2.3)$ & $2.7(1.7)$ & $4.8(2.2)$ \\
\hline Average & $2.0(1.5)$ & $3.8(2.0)$ & $5.7(2.4)$ & $5.9(2.5)$ & $5.4(2.4)$ & $3.9(2.0)$ & $2.2(1.6)$ & $4.1(2.0)$ \\
\hline $\begin{array}{l}\text { Difference } \\
\text { Difference } \\
\text { Interaction } \\
\text { dates } x \text { per }\end{array}$ & $\begin{array}{l}\text { veen pop } \\
\text { veen pop } \\
\text { ween pop } \\
\text { of obser }\end{array}$ & $\begin{array}{l}\text { tion obser } \\
\text { tion obser } \\
\text { tion obser } \\
\text { on }\end{array}$ & $\begin{array}{l}\text { in groun } \\
\text { at differ } \\
\text { in grour }\end{array}$ & $\begin{array}{l}\text { ut crops } s \\
\text { t periods o } \\
\text { hut crops s }\end{array}$ & $\begin{array}{l}\text { vn on diff } \\
\text { observatic } \\
\text { vn on diff }\end{array}$ & ent dates & $\begin{array}{l}\text { C. D. }(\mathrm{P} \\
\text { C. D. }(\mathrm{P}\end{array}$ & $\begin{array}{l}.05)=0.1 \\
.05)=1.1\end{array}$ \\
\hline
\end{tabular}

Figures in parentheses are transformed as $\sqrt{x+0.5}$; DAS $=$ Days after sowing.

The population of tobacco caterpillar was recorded for the first time at 45 days after sowing (DAS) and after attaining the peak population at 75 DAS, 105 DAS and 90 DAS showed declining trend during $2^{\text {nd }}, 1^{\text {st }}$ and $3^{\text {rd }}$ years respectively and disappeared after 135 DAS in all the three years of study (Fig. 1). The overall tobacco caterpillar population in all the three dates sown crops showed higher population during $3^{\text {rd }}$ year followed by $2^{\text {nd }}$ and $1^{\text {st }}$ years. However, the average population was maximum in $5^{\text {th }}$ July sown crop followed by $20^{\text {th }}$ June and $20^{\text {th }}$ July sown crops during different years of study (Fig.2).

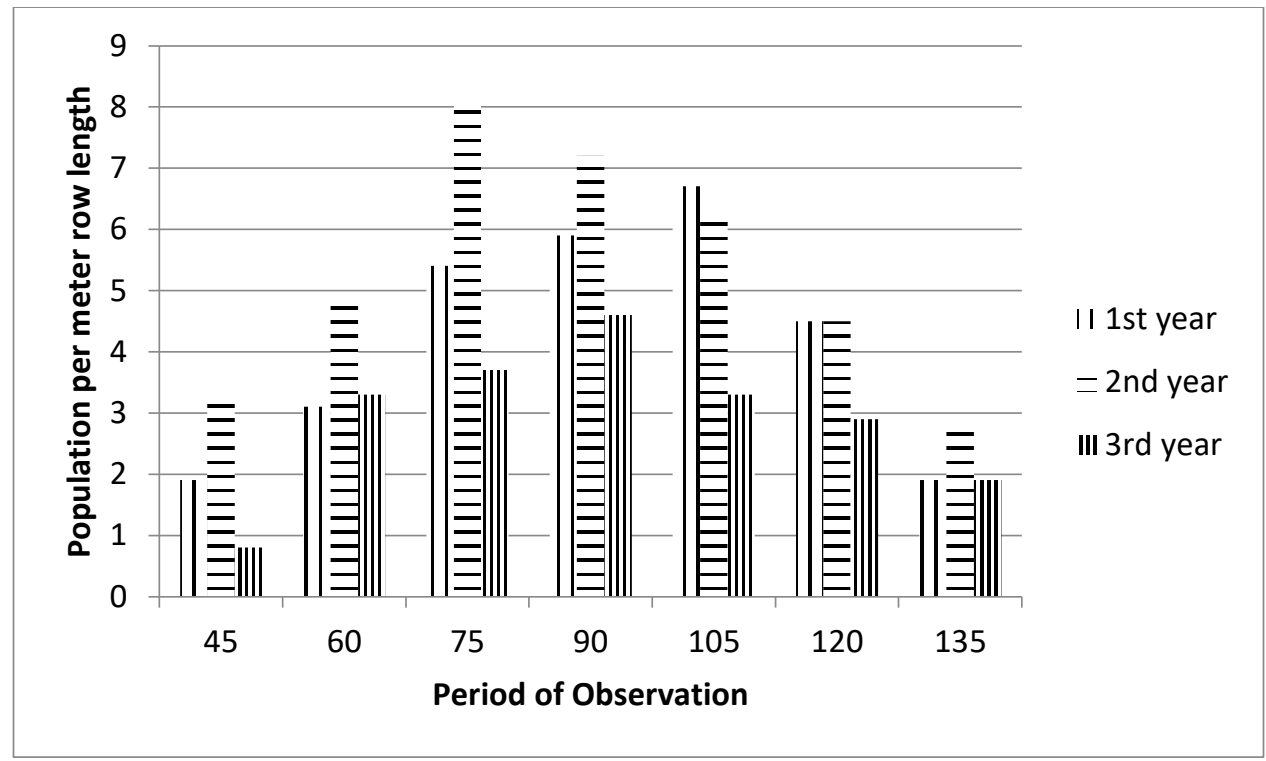

Figure 1: Temporal population distribution of tobacco caterpillar [S. litura (Fab.)] infesting groundnut crop. 




Figure 2: Population of tobacco caterpillar infesting groundnut crops sown on different dates.

The groundnut leaf damage $(\%)$ by tobacco caterpillar was maximum and minimum in groundnut crop sown on $20^{\text {th }}$ July and $20^{\text {th }}$ June respectively during all the three experimental years (Table 2). The interaction effect of sowing dates and periods of observation also showed significant effect on leaf damage $(\%)$ by tobacco caterpillar during all the three years of study The average leaf damage $(\%)$ observed at fortnightly interval followed increasing trend starting from initial infestation i.e. 45 DAS until last observation at 135 days after sowing and the leaf damage $(\%)$ observed at different dates after sowing showed significant difference (Fig. 3).

Table 2: Effect of date of sowing on the groundnut leaf damage (\%) by tobacco caterpillar [Spodoptera litura (Fab.)] (average of three years)

\begin{tabular}{|l|l|l|l|l|l|l|l|l|}
\hline $\begin{array}{l}\text { Date of } \\
\text { Sowing }\end{array}$ & $\mathbf{4 5}$ & $\mathbf{6 0}$ & $\mathbf{7 5}$ & $\mathbf{9 0}$ & $\mathbf{1 0 5}$ & $\mathbf{1 2 0}$ & $\mathbf{1 3 5}$ & Average \\
\hline $20^{\text {th }}$ June & $5.4(12.6)$ & $8.8(17.1)$ & $11.5(19.7)$ & $15.8(23.4)$ & $18.6(25.5)$ & $20.9(27.1)$ & $26.7(31.1)$ & $15.4(22.4)$ \\
\hline $5^{\text {th }}$ July & $4.9(11.1)$ & $9.2(17.7)$ & $14.0(21.9)$ & $18.3(25.4)$ & $22.3(28.1)$ & $23.8(29.0)$ & $31.0(33.8)$ & $17.7(23.8)$ \\
\hline $20^{\text {th }}$ July & $5.1(11.2)$ & $8.9(16.7)$ & $15.0(22.7)$ & $20.6(26.2)$ & $25.7(30.4)$ & $28.5(31.8)$ & $36.9(38.3)$ & $18.7(25.3)$ \\
\hline Average & $5.1(11.6)$ & $8.9(17.2)$ & $13.5(21.4)$ & $18.3(24.9)$ & $22.2(27.9)$ & $24.4(29.3)$ & $31.5(34.4)$ & $17.3(23.8)$ \\
\hline $\begin{array}{l}\text { Difference between leaf damage observed in groundnut crops sown on different dates C. D. }(\mathrm{P}=0.05)=0.7 \\
\text { Difference between leaf damage observed at different periods of observation }\end{array}$ \\
$\begin{array}{l}\text { Interaction between leaf damage observed in groundnut crops sown on different } \\
\text { C. D. }(\mathrm{P}=0.05)=1.0\end{array}$ \\
$\begin{array}{l}\text { dates x periods of observation } \\
\text { C. D. }(\mathrm{P}=0.05)=1.7\end{array}$
\end{tabular}

Figures in parentheses are Arc sine transformed values; DAS = Days after sowing. 


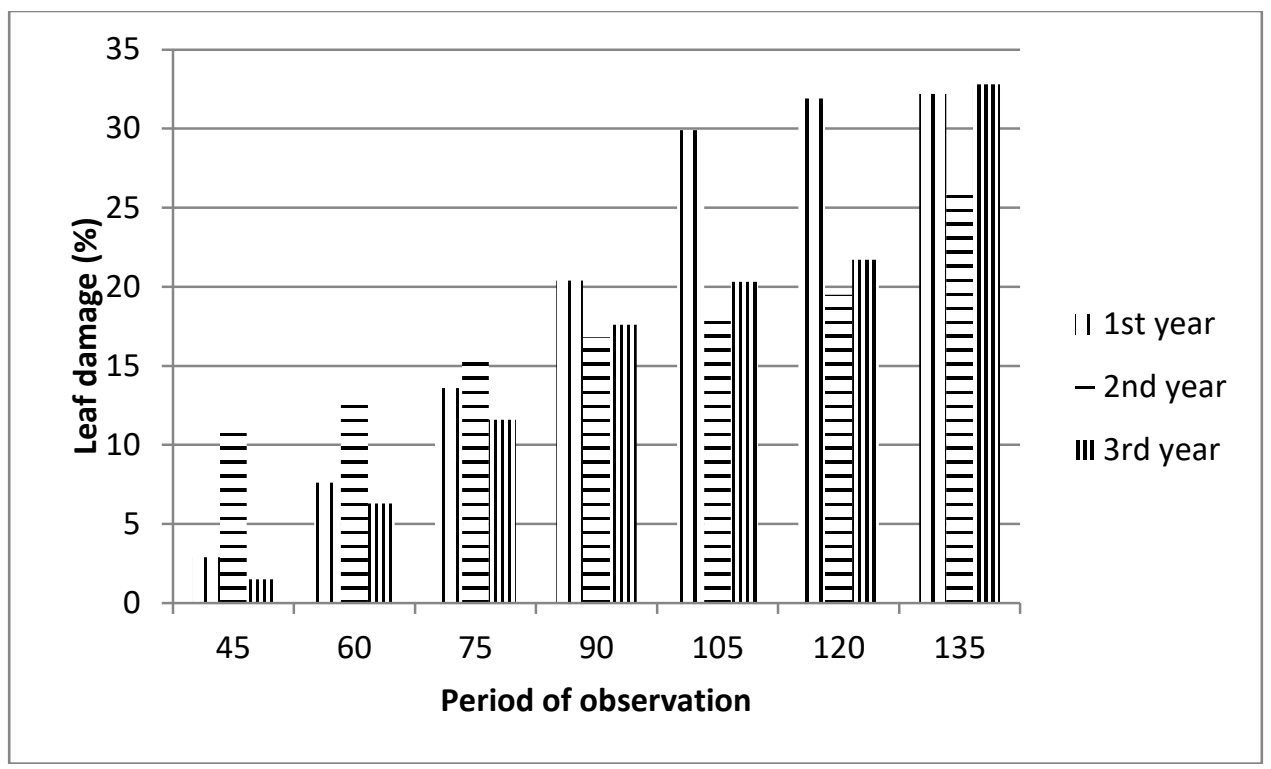

Figure 3: Temporal groundnut leaf damage by tobacco caterpillar [Spodoptera litura (Fab.)].

The average groundnut leaf damage $(\%)$ irrespective of years of study was maximum in $20^{\text {th }}$ June sown crop followed by $5^{\text {th }}$ July and $20^{\text {th }}$ July sown crops. The overall leaf damage (\%) was maximum during $3^{\text {rd }}$ year followed by $2^{\text {nd }}$ year and $1^{\text {st }}$ year of experimentation (Fig. 4$)$.

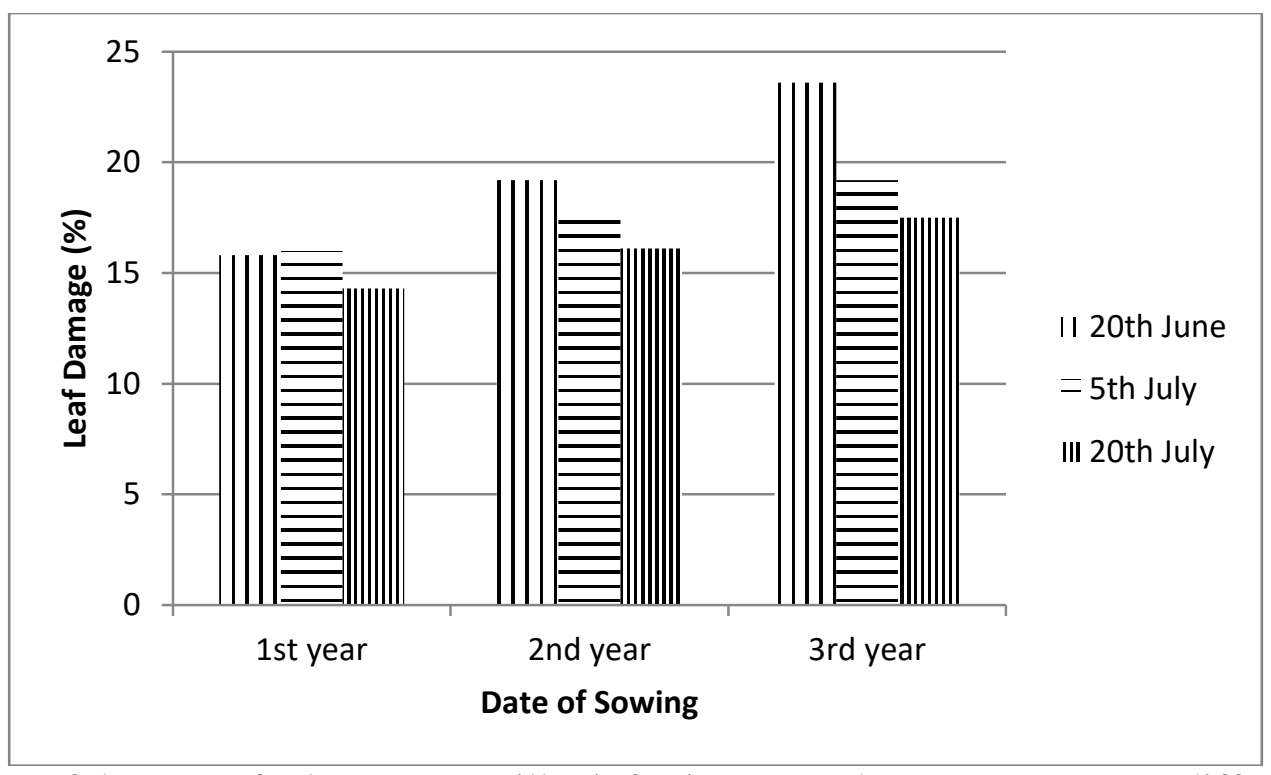

Figure 4: Leaf damage of tobacco caterpillar infesting groundnut crops sown on different dates.

The groundnut yield obtained from three different dates sown crops showed significant variation from each other (Table 3). The yield obtained from the groundnut crop sown on $20^{\text {th }}$ June was found to be maximum while $20^{\text {th }}$ July sown crop recorded minimum yield during $1^{\text {st }}, 2^{\text {nd }}$ and $3^{\text {rd }}$ years, respectively (Table 3 ). The $5^{\text {th }}$ July sown crop had intermediate pod yield. The yield of groundnut recorded during different years showed significant variation among themselves (Table 3 ). The maximum and minimum yields were recorded during $3^{\text {rd }}$ and $2^{\text {nd }}$ years, respectively. The 
yield obtained during $1^{\text {st }}$ year and the average of all the three years were found at par. The interaction effect of time of sowing and year on the groundnut yield was found to be significant.

Table 3: Effect of date of sowing and infestation of tobacco caterpillar on the yield (q/ha) of groundnut

\begin{tabular}{|c|c|c|c|c|}
\hline \multirow{3}{*}{ Sowing Times } & \multicolumn{4}{|c|}{ Yield (q/ha) } \\
\hline & \multicolumn{4}{|c|}{ Years } \\
\hline & $1^{\text {st }}$ year & $2^{\text {nd }}$ year & $3^{\text {rd }}$ year & Average \\
\hline $20^{\text {th }}$ June & 22.3 & 21.7 & 23.6 & 22.5 \\
\hline $5^{\text {th }}$ July & 21.4 & 20.2 & 23.1 & 21.6 \\
\hline $20^{\text {th }}$ July & 20.1 & 19.3 & 21.9 & 20.4 \\
\hline Average & 21.3 & 20.4 & 22.8 & 21.5 \\
\hline $\begin{array}{l}\text { Difference betw } \\
\text { Difference betw } \\
\text { Interaction betw }\end{array}$ & $\begin{array}{l}\text { yield of } \\
\text { yield of } \\
\text { yield of }\end{array}$ & $\begin{array}{l}\text { Sown on } \\
\text { sown on } \\
\text { crops sow }\end{array}$ & $\begin{array}{l}\text { ates } \\
\text { ates during } \\
\text { arent dates }\end{array}$ & $\begin{array}{r}\text { C. D. }(\mathrm{P}=0.05)=0.22 \\
\text { years C. D. }(\mathrm{P}=0.05)=0.22 \\
\text { C. D. }(\mathrm{P}=0.05)=0.21\end{array}$ \\
\hline
\end{tabular}

The results of the three years' study showed that for most favourable yield performance of groundnut $20^{\text {th }}$ June is the best time of sowing followed by $5^{\text {th }}$ July and $20^{\text {th }}$ July. The late sown crop recorded higher tobacco caterpillar population and lesser groundnut leaf damage (\%) while early sown crop produced higher yield than the crops sown on later dates. The higher population in $5^{\text {th }}$ July sown groundnut crop could be due to early and prolonged infestation of tobacco caterpillar while $20^{\text {th }}$ June sown crop though attracted tobacco caterpillars at the earliest but they were suppressed by early arrival and attack of natural enemies which mostly encountered were spiders (Oxyopes sp. and Thomisus sp.), dragonflies (Acisoma panorpoides and Rhyothemis variegate Fab.), rove beetle (Paederus fuscipes Curtis) and insect parasitoids (egg - larval parasitoid - Chelonus sp., larval parasitoid - Apanteles sp. and Cotesia sp.). The prevalence of natural enemies of tobacco caterpillar is also reported by several other workers from different cropping systems. Altogether, more than 100 species of natural enemies - parasitoids and predators have been reported from different parts of the world (Rao et al. 1993). The tobacco caterpillar is a preferred host of number of spiders (Sitaramaiah, et al, 1980). The findings of the present study are in conformity with the findings of various other workers who have reported that the monsoon based groundnut crop suffer from a number of insect pests including tobacco caterpillar (Reddy, 1988, Nath and Singh 1998b and Nath et.al., 2010 and 2011). Das and Sontakke (1994) studied the effect of four sowing dates on the incidence of insect pests and yield of groundnut during rainy season and reported that crops sown during $3^{\text {rd }}$ week of June to $1^{\text {st }}$ week of July recorded higher yield and lower incidence of insect pests compared with crops sown during $3^{\text {rd }}$ week of July to $1^{\text {st }}$ week of August. Deka et al. (1997) reported that dates of sowing of winter groundnut showed spectacular effect on growth and yield attributes of groundnut varieties. Raju et al. (1988) found that the incidence of insect was higher on the crop sown on $1^{\text {st }}$ May than the crop sown on $1^{\text {st }}$ June. These reports are in conformity with the present findings and also signifies the contribution of abiotic and biotic factors on the temporal population dynamics of tobacco caterpillar and its natural enemies. The late sown groundnut crops were relatively more succulent due to frequent rains and so high relative humidity (>70\%) during July and August months in Varanasi region of India and therefore more attractive for tobacco caterpillar. Though the early sown groundnut crop recorded higher percentage of leaf damage than the late sown crops but the long duration presence of the crop in the field helped the plant to recover the leaf damage and so yield by producing additional leaves and flowers. The 
groundnut sown on later dates have lesser time to compensate the foliage damage and therefore relatively more yield loss. Consequently, on the basis of three years study it is found that $20^{\text {th }}$ June is the most appropriate sowing time for groundnut in Varanasi region followed by $5^{\text {th }}$ July in managing the tobacco caterpillar population. Kathryn et al (2014) had reported similar results and concluded on the basis of their field experiment that early planting of chilli (January 15th or January 30th) resulted in low incidence of aphids, thrips, jassids, whitefly and fruit borer except mites. Such low level of insect pest caused less crop injury which resulted in enhancing green pod yield of chilli.

\section{Conclusion}

In the light of pooled data regarding tobacco caterpillar infesting groundnut as affected by sowing dates as a pest control measure, it is concluded that early sowing (June $20^{\text {th }}$ or July $5^{\text {th }}$ ) resulted in low incidence of tobacco caterpillar. Such low level of insect pest caused less groundnut leaf injury which resulted in enhancing the foliage and yield of groundnut. So, it is suggested that for early sowing at Varanasi region of Uttar Pradesh the appropriate sowing time can be June $20^{\text {th }}$ and/or July $5^{\text {th }}$.

\section{Acknowledgements}

Authors are thankful to the Indian Council of Agricultural Research, New Delhi for providing research funds and Banaras Hindu University for all kinds of institutional support. The first and second authors are also thankful to the Fiji National University authorities for their continuous support and encouragement.

\section{References}

[1] Reddy PS. Groundnut. Indian Council of Agriculture Research, New Delhi. 1988, 583 p.

[2] Nath P, Singh AK. Effect of intercropping of groundnut with millets and pigeonpea on the relative incidence of insect pests. Annals of Plant Protection Science. 6(2), 1998a, 151-154.

[3] Raghunathan V. Integrated Pest Management: Eco-friendly approach. The Hindu Survey of Indian Agriculture. 1996, 155 p.

[4] Singh SP. Pest Management. The Eco-friendly approach. The Hindu Survey of Indian Agriculture, 1999, pp. 175-184.

[5] Kathryn MR, Sun YY, Khan S, Baloch SU, Wu LL, Lu TT, Yang Y, Hu Z, Salam A, Iqbal S, Ali $\mathrm{S}$, Bashir W. Effect of different sowing dates on insect pest population of chillies (Capsicum annuam L.). Journal of Biology, Agriculture and Healthcare. 4 (25), 2014, 196-214.

[6] Rao G, Wightman J, Rao DR. World review of the natural enemies and diseases of Spodoptera litura (F.) (Lepidoptera: Noctuidae). Insect Science and its Application. 14(3), 1993, 273-284

[7] Sitaramaiah S, Joshi BC, Ramaprasad G. New record of spiders as predators of tobacco caterpillar Spodoptera litura F. Science and Culture. 46(1), 1980, 29-30.

[8] Nath P, Singh AK. Study of the insect pests' diversity in groundnut field and some aspect of their management. Journal of Sustainable Pest. Management. 1(1\&2) 1998b, 19-31.

[9] Nath P, Singh PS, Rai SN, Keval R. Effect of groundnut based intercroppings on the population and leaf damage by Bihar Hairy Caterpillar Spilarctia obliqua (Walk.). Indian Journal of Environment and Ecoplaning. 17(1), 2010, 251-258. 
[10] Nath P, Singh PS, Rai SN, Keval R. Effect of intercroppings of groundnut and application of pesticides on jassid (Empoasca kerri Pruthi) infesting groundnut intercropped with pigeonpea. New Agriculturist. 22(1), 2011, 85-90.

[11] Das, P. C. and Sontakke, B. K. Effect of sowing dates on insect pests incidence and yield of kharif groundnut under western Orissa conditions. Orissa Journal of Agriculture Research. 7(34), 1994, 63-66.

[12] Deka NC, Gogoi PK, Baroova SR, Rajkhowa DJ. Effect of sowing dates on groundnut varieties on upper Brahmaputra valley zone of Assam. Annals of Agriculture Research. 18(1), 1997, 2124.

[13] Raju AK, Rao PRM, Rao RVA, Azam KM, Reddy AS. Influence of sowing time on the incidence of leaf minor of groundnut vs. yield. Journal of Research APAU. 16(2), 1988, 160-161.

*Corresponding author.

E-mail address: S. N. Rai, Department of Entomology \& Plant Pathology, College of Agriculture, Fisheries and Forestry, Fiji National University, P.O. Box 1544, Nausori, Fiji Islands, E. mail: sachchida.rai@fnu.ac.fj, FAX +6793400275 